University of Louisville

ThinkIR: The University of Louisville's Institutional Repository

Electronic Theses and Dissertations

$6-1920$

\title{
Nitrogenous constituents of condensed milk, with special reference to total non-protein nitrogen, urea nitrogen and uric acid.
}

Bess Burton Mathis

University of Louisville

Follow this and additional works at: https://ir.library.louisville.edu/etd

\section{Recommended Citation}

Mathis, Bess Burton, "Nitrogenous constituents of condensed milk, with special reference to total nonprotein nitrogen, urea nitrogen and uric acid." (1920). Electronic Theses and Dissertations. Paper 921. https://doi.org/10.18297/etd/921

This Master's Thesis is brought to you for free and open access by ThinkIR: The University of Louisville's Institutional Repository. It has been accepted for inclusion in Electronic Theses and Dissertations by an authorized administrator of ThinkIR: The University of Louisville's Institutional Repository. This title appears here courtesy of the author, who has retained all other copyrights. For more information, please contact thinkir@louisville.edu. 
NITROGENOUS CONSTITUENTS OF CONDENSED MILK, WITH SPECIAL REFERENCE TO TOTAL NON-PROTEIN NITFOGEN, UREA NITPOGEN, AND URIC ACID.

A Thesis Submitted to the Faculty of the College of Arts and Sclences

$$
\text { of the }
$$

U N I V E R S I T Y O F L O U I S V I L L E Through Dr. A. W. Homberger, In Candidacy for the Degree MASTER OF SCIENCE.

$$
\text { by. }
$$

Bess Burton Methis. 


\title{
NITROGENOUS CONSTITUENTS OF CONDENSED IIILK,
}

\author{
TITH SPECIAL REFERENCE TO \\ TOTAL NON-PROTEIN NITROGEN, \\ UREA NITROGEN, AND URIC ACID. \\ $* * * * * * *$
}

The most important non-protein nitrogenous constituents of milk are urea, creatinine, creatine, and uric acid.

Urea is the diamide of carbonic acid

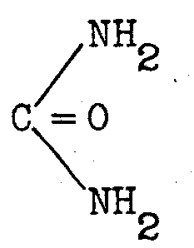

and is the chief end-product, so far as nitrogen is concerned, of the physiological metabolism of the proteins of the foods and tissues. It has long been considered a matter of greatest importance to ascertain in what organ or tissues urea is formed. Investigations have gone so far as to demonstrate that it arises in part, at least, in the liver - that the liver cells are able to convert ammonium carbonate into urea which is then given to the blood and excreted by the kidney. It occurs in urine in relatively large quantities (two per cent), and is found also in slight quantities in other secretions - in milk, in traces, and in sweat. Urea is present normally in the blood in an amount equal to .028 per cent, and it has been shown that the tissues 
generally contain urea in about the same concentration. The history of the formation of urea in the body is not entirely known; but three sources of origin may be stated with some positiveness:

First, urea arises from ammonia salts which, in the liver, are converted into urea by a process equivalent to dehydration. The reaction may be represented as follows:

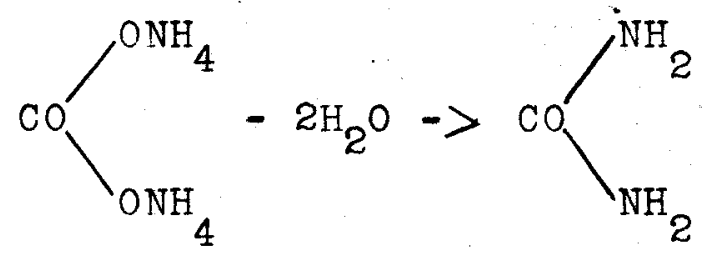

It would seem that the liver protects the body from the poisonous action of the ammonia compounds by converting them to urea, while in the same process, some of the $\mathrm{CO}_{2}$ formed in the body is neutralized and prepared for excretion.

Second, urea arises from the mono-amino acids by a process of deaminization, whereby the $\mathrm{NH}_{2}$ group is converted to ammonia and then probably to urea. There is evidence to show that this process of deaminization, as well as the further conversion of the ammonia to urea, takes place in the liver, although it is quite possible that both functions may be exhibited by other tissues as well. 


\section{3.}

On a large protein diet, the amount of nitrogenous material supplied is in excess of the amount needed for tissue construction. On this view we can understand why the amount of urea eliminated in the urine rises and falls with the amount of protein taken as food. It may be supposed that the excess nitrogen is promptly removed and excreted as urea. But on the lowest protein diet or in starvation, when the body is living on its own tissues, urea continues to be formed, so that, in part, the urea of the urine represents nitrogen which has probably arisen from the destruction of protein tissue. The intermediate steps in this latter process are not definitely known, but probably they are analagous - that is, the protein passes through the stage of amino aclds and subsequently undergoes deaminization.

Third, urea may arise from the arginine formed in the cleavage of the protein molecule by conversion of the contained guanidine radical. Unlike cases one and two, the urea in this instance is formed from the guanidine residue contained in the arginine and not from the amino groups. Since arginine constitutes one of the split products of the proteinsduring digestion, and probably also oneff the split products in the metabolism 
of the protein of the tissues, there is reason to believe that part of the urea actually formed in the body arises by this method.

Urea has several quite important physiological actions. In the first place, it is a natural diuretic. Then tissues live much longer in the presence of some urea than in its absence. It has also a very definite function in the cells of some fishes, and possibly in mammalia also. It is one of the normal constituents of the cell and of the blood and other fluids of the body, and since these cells have for long years of time been selected to work with the highest degree of efficiency in this urea-containing medium, it is found that the addition of a little urea to artificial perfusion solutions is advantageous. The effect on mammalia is much less marked, since the amount of urea in the blood of mammals is very small, .02 to .04 per cent.

Urea is not, then, entirely inert. Creatinine or methyl-guanidine-acetic acid anhydride

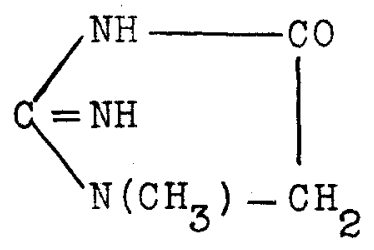


next to urea and the ammonia compounds, forms the most important constituent of urine. It occurs also in sweat, in milk, and in the muscles of fishes. Its physiological history is imperfectly known. Under constant conditions of life, the amount of creatinine formed in the body is independent of the quantity of protein eaten, and this fact indicates that it repre-. sents an end-product of the metabolism of living or organized protein tissue rather than one of the results of the metabolism of the food protein. But while the creatinine excretion is independent of the protein of the food, it is affected by the intake of creatine or creatinine. The ingestion of creatinine is followed by the reappearance of most of it in the urine. Creatinine is present in small amounts in the blood and in somewhat larger amounts in muscular tissue.

Creatine or methyl-guanldine-acetic acid

$$
\overbrace{\mathrm{N}\left(\mathrm{CH}_{3}\right) \cdot \mathrm{CH}_{2} \mathrm{COOH}}^{\mathrm{NH}_{2}}
$$

on the other hand, is present in muscular tissue to a relatively large percentage, 0.5 to 0.6 grams per one hundred grams of muscle, although Folin contends that 
this large yield is due to post-mortem changes, and that in living muscle little or none is present in free condition. Creatine occurs in the blood in small amounts, and in the urine of infants and children. It also occurs under all conditions in which the body e1ther has no sugar to burn or is unable to burn it; in starvation, diabetis, and sepsis. It occurs, too, under circumstances of exaggerated wasting of muscle substance. According to one view, the creatine and creatinine are related and have a common physiological significance in regard to the metabolism.

Creatine is regarded as an end-procuct of the break-down of organized or living protein tissue. It is produced constantiy in the tissues and is normally converted to creatinine before it is excreted in the urine. other observers believe that the metabolic history and significance of creatine and creatinine are different. The creatinine formed in the tissues represents an endproduct of the breaking down of the organized tissue and, indeed, forms an index of the amount of this tissue wear and tear, but it is given off to the blood and is excreted in the urine as creatinine. The creatine, on the contrary, while also constantly formed in the tissues as a result of their metabolism is not converted to 


\section{7.}

creatinine, but undergoes some further and as yet unknown metabolic change. The difficulty in accepting the hypothesis of creatine destruction lies in the fact that most of the nitrogen of the ingested creatine does not appear in the urine, nor have Folin or others found evidence to warrant accepting its transformation into urea or ammonia. We can only come to the conclusion that in such instances the creatine was being stored. On this view, the significance of the creatine remains undetermined, and its genesis and fate are also left unsettled, except so far as to deny its conversion to creatinine. Steenbock and Gross are convinced that in one form or another creatinuria is etiologically related to protein metabolism, whether of exogenous or endogenous origin, and that in addition, in a manner as yet unlenown, it is related to the creatine stored in the muscles and other tissues as well. Reduced to its simplest terms, the present immediate problem resolves itself into a consideration of the mechanism of the formation of ald creatine. According to their hypothesis, creatine is an end-product in the catabolism of certain precursors in the protein molocule just as urea is of others. The animal body has a fairly defirite ability to destroy creatine, and in creatinuria, creatine has been produced 
in such amounts that the ability of the body to destroy it has been exceeded.

Results of experiments by Gamble and Goldschmidt show that the infant differs radically from the adult in its behavior toward ingested creatine - that small amounts of ingested creatine lead to an increase of the creatinuria. Results of other experiments performed by them indicate that the creatine excretion. of infants hears a relation to the quantity of cow's milk fed, and also other results indicate that the quantity of whey given is more directly related to the degree of creatinuria than is the total protein value of the food. on the assumption that preformed creatine in milk modifications is in proportion to the quantity of whey present, the results suggest that the ingestion of creatine is probably a large factor in the creatinuria of infants fed on cow's milk.

There is no indication that creatine has any specific role to perform in the animal bocy unless it is that, by reversible reaction it can serve as a source of guanidine grouping for arginine synthesis.

There are several possible sources of creatine in the body, although the ultimate origin of it is uncertain. It is related, on the one hand, to arginine from 
which it might possibly be derived by oxidation and methylation. Creatine is a methylated amino acid, a point of much interst since none of the amino acids of the proteins are known to be methylated. On the other hand, it may be regarded as an imidazole derivative. It is thus allied to histidine and to the purines, both of which contain imidazole rings.

Uric acid, or $2,6,8$, tri-oxypurine

$$
\begin{aligned}
& \mathrm{H}-\mathrm{N}-\mathrm{C}=\mathrm{O} \\
& \mathrm{I} \quad \mathrm{I} \\
& \mathrm{O}=\mathrm{C} \quad \mathrm{C}-\mathrm{NH} \\
& \mathrm{I} \\
& \mathrm{H}-\mathrm{N}-\mathrm{N}-\mathrm{NH}
\end{aligned}
$$

Lactam form.

$$
\begin{aligned}
& \mathrm{N}=\mathrm{C}-\mathrm{OH} \\
& \begin{array}{ll}
\text { l } & 1 \\
\mathrm{C} & \mathrm{C}-\mathrm{NH}
\end{array} \\
& \| \stackrel{N}{ }=\mathrm{C}-\mathrm{N} \geqslant \mathrm{C}-\mathrm{OH}(8)
\end{aligned}
$$

Lactim form.

is of very particular interest because of its relation to nuclear metabolism. It was long believed that uric acid in urine was an intermediary product of protein metabolism, which was usually almost completely oxidized by the body to urea. However, we now know that uric acld does not come from the ordinary protein metabolism. The end-product of that metabolism is urea; but It comes from the metabolism of the nucleins, both of those of the food and those of the tissues.

The nucleins, it will be rememhered, contain nucleic acid, and nucleic acid contains purines, which when oxidized, form uric acid. 
There is no doubt that the ingestion of nucleins increases the excretion of uric acid, and the elimination of nucleins from the diet decreases the excretion to a certain minimum, but does not abolish it entirely. Therefore, some of the uric acid of the urine has an exogenous source. But by cutting the nucleins completely out of the food, or by starving, It is not possible to suppress the uric acid excretion entirely. This residual uric acid evidently must have its origin either in the body tissues or else in the bodies of the bacteria of the alimentary canal. Since there is reasonfor thinking that the nuclei of the body cells are undergoing metabolism it is generally believed that this uric acid takes its origin, largely at least, from the nucleins of the tissue nuclei. So there is also uric acid of endogenous origin in the urine.

There are in nearly all cells, and possibly in all cells, autolytic or endocellular enzymes, or nucleases, which decompose nucleic acid into its various constituents. The various cleavages appear in the autolysis of different cells and are belleved to be due to different nucleases. At any rate, the purine bases are set free in most autolyses. It is, on the 
whole, probable that some members of the group of enzymes are found in all tissues of the body, since the partial conversion of guanine and adenine in their nucleic acids to hypoxanthine and xanthine on autolysis, appears to be a very common, if not a universal phenomenon. In man, the uric acid, xanthine, and hypoxanthine represent the final end-products of the metabolism of - nucleic acid, or, rather, of the purine nucleotide portion of its molecule, and the extent to which they occur in the urine indicates so much nucleic acid broken down. Uric acid is but one of the purines. Purines are important constituents of the most important constituents of living matter, namely the chromatin of the cell nuclei. The very pregnant question remains behind, namely, can the animal organism make its purines from other nitrogenous material of a non-protein kind, or. must it depend entirely on purine materials in the food? Probably no nitrogenous substance in the urine has been more studied than uric acid. Although present in small quantities, it has long attracted attention because of the problems involved in its origin, its significant variation in disease, its insolubility, and above all, because of its deposition in the joints in the form of crystalline insoluble salts. 
All of these non-protein nitrogenous compounds referred to, occur in small quantities in both cow's and human milk. Denis and Minot have found the amount of total non-protein nitrogen in cow's milk to be about $22.9 \mathrm{mg}$. per $100 \mathrm{cc}$, and of this total, $9.3 \mathrm{mg}$. occur as urea nitrogen, $4.3 \mathrm{mg}$. occur as creatinine, $2.4 \mathrm{mg}$. are present as creatine, while $1.5 \mathrm{mg}$. are in the form of uric acid. The total non-protein nitrogen in human milk amounts to about $33 \mathrm{mg}$. per $100 \mathrm{cc}$, of which $12.6 \mathrm{mg}$. are found as urea nitrogen, $1.5 \mathrm{mg}$. occur as creatinine, $3.5 \mathrm{mg}$. are in the form of creatine, and $2.5 \mathrm{mg}$. are present as uric acid.

Whether these nitrogenous substances present In milk and in other foods are in any way responsible for the non-protein nitrogenous constituents found in urine is as yet unknown, although such a relationship would seem highly probable.

It has been the object of my experiments to determine whether or not the process of condensing cow's milk in any way changes the amounts of total non-protein nitrogen, urea nitrogen, or uric acid present in the milk.

The three brands of condensed milk, Pet, Carnation, and Wilson, were used in the experiments, and 
the methods employed were those described by Denis and Minot in the Journal of Biological Chemistry, March, 1919, pages 355, 357, and 364 .

No difficulty was encountered in the application of the methods for the determination of urea nitrogen and uric acld, but a slight modification was necessary in the case of total nitrogen. When the milk filtrate, freed from poin, carbohydrate, and fat, and digested with the acid digestion mixture, was diluted to a volume of $25-50 \mathrm{cc}$. , it was found that it could not be successfully Nesslerized. The difficulty seemed to be in the concentration. The method finally adopted was a modification of that of Folin and Wu. It is as follows: Take $20 \mathrm{cc}$. of protein-free milk filtrate and introduce 1t into a large test tube. Add to this I cc. of acid digestion mixture (see 1. below) and a small pebble. Heat this tube with its contents over a low flame to bolling, continue to boil until the dark mixture turns water white, allow the tube to 2001 and make the volume up to $100 \mathrm{cc}$. In a volumetric flask. From this solution draw out $25 \mathrm{cc}$. and Nesslerize with $15 \mathrm{cc}$. of Nessler's solution. The standard is prepared as follows: Introduce $1.5 \mathrm{cc}$. of ammonium sulphate ( 1 cc: $:=22.949 \mathrm{mg}$. nitrogen) into a $100 \mathrm{cc}$. volumetric 
flask, and add $I$ cc. of the acid digestion mixture. Make this up to $100 \mathrm{cc}$. with distilled water. Draw out $25 \mathrm{cc}$. and Nesslerize with $15 \mathrm{cc}$. of Nessler's solution.

(1) The acid digestion mixture is made by taking $100 \mathrm{cc}$. of $85 \%$ phosphoric acid, $300 \mathrm{cc}$. of concentrated sulphuric acid, and $15 \mathrm{cc}$. of a $10 \%$ copper sulphate solution. Mix these thoroughly.

At the beginning of each determination the condensed milk was diluted with distilled water until the specific grevity was the same as that of cow's milk.

Practically the same difficulty was encountered in the determination of non-protein nitrogen in blood by the method of Folin and Denis. The acid digestion mixture recommended by Denis and Minot was found to give better results than that described by Folin and Wu. in their modffication of the method of Folin and Denis. The procedure is as follows: Take $5 \mathrm{cc}$. of proteinfree blood filtrate and introduce into a large test tube. Add to this $I \mathrm{cc}$. of acid digestion mixture (see 1 . below) and a small pebble. Heat this tube with its contents over a low flame to bolling, continue to boil until the dark mixture turns water white, allow the tube to $\mathrm{cool}$ and make the volume up to $100 \mathrm{cc}$. In a volumetric 
flask, with distilled water. From this solution draw out $25 \mathrm{cc}$. and Nesslerize with $15 \mathrm{cc}$. of Nessler's solution.

(I) The acid digestion mixture is that described by Denis and Minot in the Journal of Biological Chemistry, March, 1919, page 356. The standard is prepared as follows: Introduce $1 \mathrm{cc}$. of ammonium sulphate ( $1 \mathrm{cc} \cdot=$ $0.3 \mathrm{mg}$. nitrogen) into a $100 \mathrm{cc}$. volumetric flask, and add $1 \mathrm{cc}$. of the acid digestion mixture. Make this up to $100 \mathrm{cc}$. With distilled water. Dram out $25 \mathrm{cc}$. and Nesslerize with $15 \mathrm{cc}$. of Nessler's solution.

A series of experiments on Pet, Carnation, and Wilson brands of condensed milk with regard to the amounts of total non-protein nitrogen, urea nitrogen, and uric acid present showed the following results:

Pet (mg. per $100 \mathrm{cc}$ : of milk)

Total Non-Protein Nitrogen
Urea

14.60

14.00

13.90

13.76

14.15

14.54
Uric Acid

0.34

0.35

0.31

0.35

0.30

0.33 
16.

Carnation (ing. per $100 \mathrm{cc}$. of milk)

$\begin{array}{ccc}\begin{array}{c}\text { Total Non-Protein } \\ \text { Nitrogen }\end{array} & \text { Urea } & \text { Uric Acid } \\ 28.63 & & \\ 30.54 & 11.8 & 0.32 \\ 26.51 & 13.1 & 0.32 \\ 29.39 & 13.3 & 0.31 \\ 29.77 & 12.6 & 0.32 \\ 29.20 & 11.9 & 0.30 \\ & 13.1 & 0.32 \\ & & \\ & & \\ \text { Wilson } & \text { (mg. per } 100 \text { cc. of milk) } \\ & & \\ \text { Total Non-Protein } & \text { Urea } & \text { Uric Acid } \\ \text { N1trogen } & & \\ 22.48 & 13.8 & 0.36 \\ 20.78 & 15.6 & 0.32 \\ 19.72 & 16.3 & 0.30 \\ 24.94 & 14.8 & 0.31 \\ 22.16 & 15.1 & \\ 21.32 & 14.9 & \end{array}$


These results indicate that the amount of total non-protein nitrogen present in condensed milk is practically the same as that recovered from cow's milk by the methods of Denis and Minot. The quantity of urea in condensed milk, however, is considerably greater than that in the uncondensed milk, the former, in some instances, showing an increase of from one third to one half in urea nitrogen. At the same time, the amount of uric acid recovered shows a marked decrease as compared with cow's milk, about one fourth as much uric acid being present after the process of condensing. Due to the fact that such conditions exist, it is probable that an internal molecular - rearrangement of the nitrogenous constituents of the milk has taken place -- that in the process of evaporation some of the uric acid and other purine bases have been converted into urea. There cannot have been, from our results, any loss in the nitrogenous constituents, in total that the non-protein nitrogen remained constant. The rearrangement must have taken place in the breaking down of the uric acid. The results obtained point distinctly to a rearrangement of the nitrogenous constituents. 
$* * *$

B I B L I O G R A P H Y

$* * *$ 


\section{Bibliography.}

$* * * *$

Howell Text Book of Physiology. Ed. 7

Pages $835,853-860$.

Ma thews

Physlological Chemistry. Ed. 2.

Pages 687-736.

Allen Commercial Organic Analysis. Ed. 4. Vol.7. Pages 308-317.

Journal of Blological Chemistry, March 1919.

Pages 353-358, 364-366.

Journal of Biólogical Chemistry, November 1919.

Pages 199-225.

Journal of Biological Chemistry, November 1918.

Pages 265-289. 